\title{
СТРУКТУРА МОДЕЛІ ПРОГРАМИ ЗДОРОВ'ЯЗБЕРІГАЮЧӦ̈ СПРЯМОВАНОСТІ НА ЕТАПІ ПОПЕРЕДНЬОЇ БАЗОВОЇ ПІДГОТОВКИ У ЮНИХ ФУТБОЛІСТІВ 3 ФУНКЦІОНАЛЬНИМИ ПОРУШЕННЯМИ ОПОРНО-РУХОВОГО АПАРАТУ
}

\begin{abstract}
Мета. Розробити модель програм здоров'язберігаючої спрямованості на етапі попередньої базової підготовки у юних футболістів з функціональними порушеннями опорно-рухового апарату. Методи. Аналіз даних науково-методичної літератури й інформачійних ресурсів мережі Інтернет, контент-аналіз теоретичних і методичних робіт, реконструкція, синтез. За даними наукової спільноти властива сучасному дитячо-юнацькому спорту інтенсифікачія навчально-тренувального процесу, спрямована на досягнення високих спортивних результатів, призводить до збільшення навантажень на дитячий організм і може спричинити виникнення в юних спортсменів метаболічних, морфо-функціональних порушень, донозологічних станів і захворювань. Сьогодні все більшу актуальність набуває проблема профілактики, раннє виявлення і корекції порушень станів кістково-м'язової системи юних спортсменів. Враховуючи фундаментальні розробки теорії та методики юнацького спорту, біомеханіки просторової організації тіла людини, специфіку планування фізичних навантажень з акцентом на особливості організму юних спортсменів, розроблено модель програм здоров'язберігаючої спрямованості футболістів 3 функціональними порушеннями опорно-рухового апарату на етапі попередньої базової підготовки та технологічні операчії, яка включає два взаємопов'язаних блоки: організачійно-методичний та змістовноиільовий. Організачійно-методичний блок моделі програм здоров'язберігаючої спрямованості футболістів з функціональними порушеннями опорно-рухового апарату на етапі попередньої базової підготовки передбачає організацію попередньої підготовчо-методичної роботи зі створення здоров'язберігаючого середовища. У змістовно-цільовий блок програм входили мета, завдання, засоби, форми і методи корекційнопрофілактичних заходів, принциии і методи проектування і реалізачії здоров 'язберігаючої технології.
\end{abstract}

Ключові слова: юні футболісти, модель, програми здоров'язберігаючої спрямованості, порушення постави.

Aim. To develop a model of health-preserving oriented programs at preliminary basic training stage in young football players with functional musculoskeletal system disorders. Methods. Data analysis of scientific and methodical literature and Internet information resources, content analysis of theoretical and methodical works, reconstruction and synthesis. According to the scientific community, the educational and training process intensification, characteristic for modern children's and youth sports, aimed at achieving high sports results, increases the load on the child's body and can cause metabolic, morpho-functional disorders, prenosological conditions and diseases in young athletes. Today, the problem of prevention, early detection and correction of musculoskeletal system disorders in young athletes is becoming increasingly important. Taking into account the fundamental developments of the youth sports theory and methods, biomechanics of spatial human body organization, the specifics of physical trainings planning emphasizing on young athletes body peculiarities, there was developed a model of health-preserving oriented programs at preliminary basic training stage in young football players with functional musculoskeletal system disorders at preliminary basic training stage and technological operations, which includes two interrelated blocks: organizational-methodical and content-target. The organizational and methodological block of the model of health-preserving oriented programs at preliminary basic training stage in young football players with functional musculoskeletal system disorders at preliminary basic training stage requires the organization of preliminary preparatory-methodical work on healthpreserving environment creating. The content-target programs block included the purpose, tasks, means, forms and methods of corrective and preventive measures, principles and methods of health-preserving technology planning and implementation.

Keywords: young football players, model, health-preserving programs, posture disorders.

Постановка проблеми й аналіз результатів останніх досліджень. У теорії спорту питанням стану здоров'я спортсменів приділяється особлива увага внаслідок їх тісному взаємозв'язку з проблемою ефективності процесу багаторічної спортивної підготовки $[3,5,7]$.

За даними наукової спільноти $[6,15,16]$ властива сучасному дитячо-юнацькому спорту інтенсифікація навчально-тренувального процесу, спрямована на досягнення 
високих спортивних результатів, призводить до збільшення навантажень на дитячий організм і може спричинити виникнення в юних спортсменів метаболічних, морфофункціональних порушень, донозологічних станів і захворювань [14].

Сьогодні все більшу актуальність набуває проблема профілактики, раннє виявлення і корекції порушень станів кістково-м'язової системи юних спортсменів $[1,2,4]$. Згідно 3 наявними уявленнями $[10,11,17]$ порушення величин фізіологічних вигинів хребтового стовпа, гіпермобільність суглобів, поперечна і поздовжня плоскостопість та ін. $\epsilon$ маркерами з'єднувально-тканинних дисплазій, які можуть стати однією із серйозних причин перевантаження різних відділів опорно-рухового апарату (ОРА) у спортсменів, що в подальшому може призвести до виникнення травм і захворювань як самого ОРА, так і внутрішніх органів.

3 огляду на вищевикладене видається беззаперечною актуальність пошуку шляхів і створення науково-методичних розробок із надання процесу підготовки юних спортсменів здоров'язберігаючої спрямованості на основі її вдосконалення за допомогою введення системи корекційно-профілактичних заходів.

Зв'язок з науковими темами та напрямками. Зв'язок із важливими науковими чи практичними завданнями. Роботу виконано згідно до плану науково-дослідної роботи ДВНЗ “Прикарпатський національний університет імені Василя Стефаника" на 2015-2020 pр. на тему “Теоретико-методичні основи диференційованого фізичного виховання в дошкільних закладах освіти, школах і позашкільних установах та закладах вищої освіти" (номер державної реєстрації 0116U003890) на (номер державної реєстрації 0110U001671).

Мета дослідження - розробити модель програм здоров'язберігаючої спрямованості на етапі попередньої базової підготовки у юних футболістів з функціональними порушеннями опорно-рухового апарату.

Методи дослідження. Предмет і специфіка дослідження зумовили потребу комплексного застосування теоретичних методів: систематизації, аналізу даних науковометодичної літератури й інформаційних ресурсів мережі Інтернет, контент-аналізу теоретичних і методичних робіт - для вивчення актуальності питання поширення порушень опорно-рухового апарату (ОРА) юних спортсменів, а також узагальнення наукових підходів до добору засобів і програм здоров'язберігаючої спрямованості юних спортсменів із нефіксованими порушеннями ОРА; аналізу практичного досвіду фахівців із означеної проблеми (монографій, дисертаційних робіт, наукових публікацій із проблем планування та організації навчально-тренувального процесу здоров'язберігаючої спрямованості) - для осмислення специфіки розвитку нефіксованих порушень ОРА та факторівдетермінантів їхньої поширеності серед юних спортсменів, що постають векторами значущості здоров'язберігаючої спрямованості як одного зі складників системи медикобіологічного забезпечення процесу багаторічної підготовки спортсменів; планування вивчення літературних даних: проблемного аналізу, реконструкції, синтезу.

Результати досліджень. Розроблена нами структурно-змістовна модель програм здоров'язберігаючої спрямованості футболістів з функціональними порушеннями ОРА на етапі попередньої базової підготовки включає два взаємопов'язаних блоки: організаиійно-методичний, змістовно-иілььовий.

Організаційно-методичний блок моделі передбачає організацію попередньої підготовчо-методичної роботи зі створення здоров'язберігаючого середовища; відбір доступних засобів спортивного тренування, складання плану, програми та розкладу корекційно-профілактичних заходів, підготовку спортивного інвентарю, ознайомлення юних спортсменів з особливостями виконання корекційних вправ.

У змістовно-цільовий блок програм входили мета, завдання, засоби, форми і методи корекційно-профілактичних заходів, принципи і методи проектування і реалізації 
здоров'язберігаючої технології. Значну увагу в ньому було приділено формуванню умінь самостійно займатися корекційними фізичними вправами і формування теоретичних знань у юних футболістів про здоров'я, здоровий спосіб життя (ЗСЖ), правильну поставу.

Здоров'язберігаючі програми, які ми пропонуємо, що призначені для юних футболістів, складаються з двох взаємопов'язаних частин: теоретичної та практичної.

У нашому випадку теоретична частина моделі була спрямована на формування гігієнічних знань і формування умінь і навичок, необхідних для підвищення рівня стану біогеометричного профілю постави, корекцію і профілактику функціональних порушень OPA збереження і зміцнення здоров'я, формування ЗСЖ та попередження патологічних станів у юних спортсменів.

Проведення теоретичної підготовки грунтувалися на план-схему річного циклу підготовки для навчально-тренувальних груп 2-го року навчання.

Тематичний план теоретичної підготовки юних футболістів включає “Відомості про будову $i$ функиії організму людини”. 3 огляду на цей факт, в даний розділ ми включили мультимедіа презентації, які розкривають особливості правильної постави, функціональних порушень ОРА, засоби профілактики та корекції порушень просторової організації тіла людини (рис. 1).

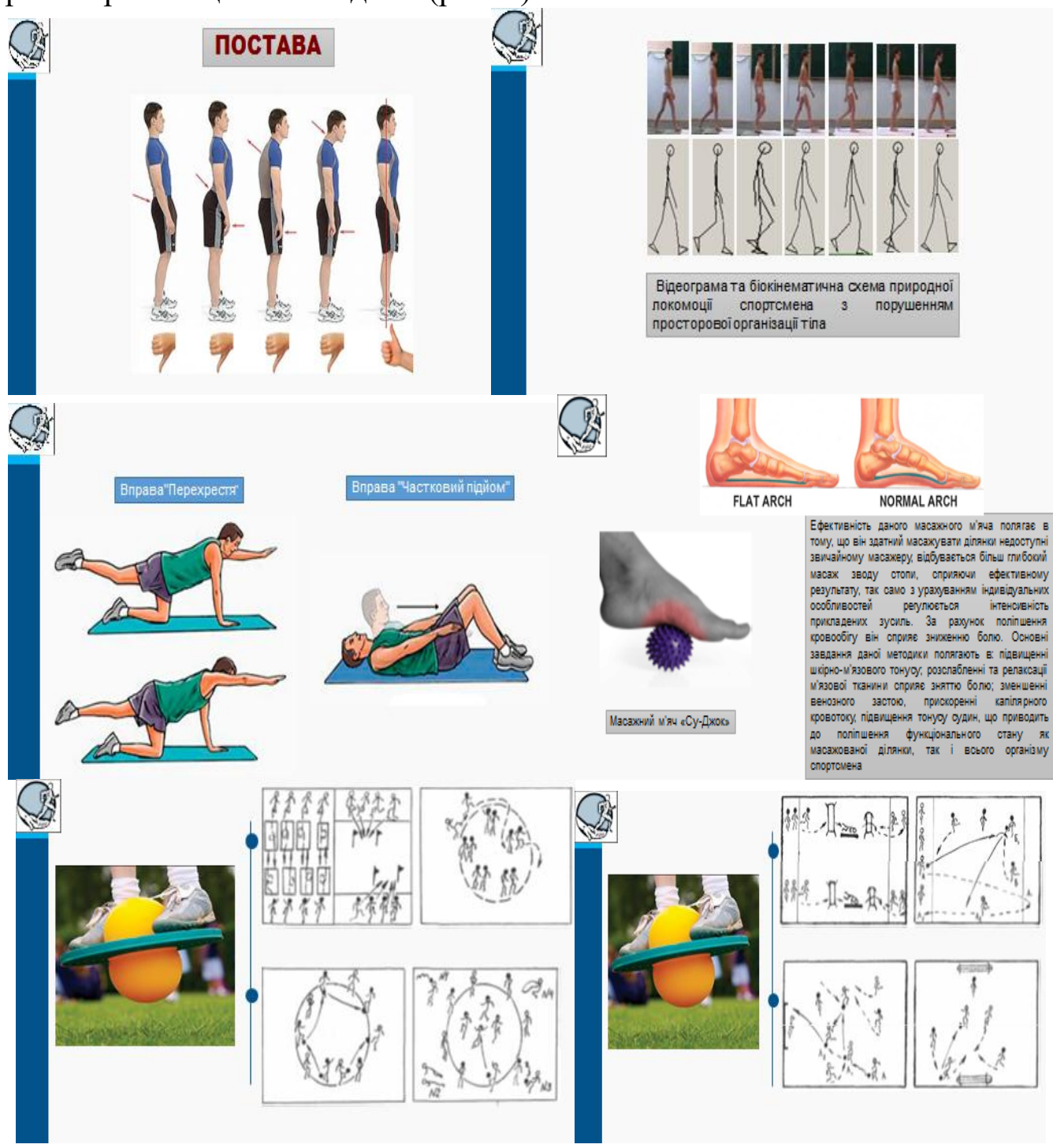

Рuc. 1. Мультимедійна презентація "Постава". 
Спеціальне акцентування щодо здоров'язберігаючої спрямованості підготовки в загальному плані побудови навчально-тренувального процесу вже на етапі попередньої базової підготовки представляється неодмінною умовою вдосконалення організації та управління процесом формування просторової організації тіла футболістів. При цьому організація і реалізація корекційно-профілактичних заходів повинні базуватися на передовій методології, мати в своєму розпорядженні необхідні технологічні схеми, вирішувати специфічні завдання по забезпеченню цілеспрямованої комплексної підготовки юних футболістів з урахуванням індивідуальних особливостей просторової організації їх тіла.

Протягом спортивної кар'єри основна частина фізичного навантаження припадає на хребет атлета $[10,11]$. В цілому, всі ланки тіла спортсмена включені в роботу, ефективність якої залежить від раціональності рухів біокінематичних пар ОРА. Біокінематичні пари активно беруть участь в рухових діях різної координації, складності та потужності. У той же час, нерівномірний розподіл навантаження між м'язовими групами може привести до порушень просторової організації тіла юного спортсмена [8, 13]. У зв'язку з цим, при плануванні та організації навчально-тренувального процесу здоров'язберігаючої спрямованості юних футболістів домінуючим напрямком стають біомеханічні технології які спираються на закони біомеханіки, що забезпечують ефективність функціонування біокінематичних пар і ланцюгів ОРА.

Аналіз матеріалів науково-методичної літератури $[8,13]$ дозволив визначити вимоги до вправ з метою корекції функціональних порушень постави та підвищення рівня стану його біогеометричного профілю у юних футболістів:

1. Ігрові корекційні вправи повинні відображати специфічну діяльність футболістів.

2. Ігрові вправи повинні бути спрямовані на формування правильної статодинамичної постави.

3. Фізичні вправи повинні бути спрямовані на формування і закріплення навиків статодинамічної постави, яка характеризується ортоградним положенням тіла, що знаходиться у рівновазі і зміною в динаміці пози, і положення тіла з плином часу. При цьому ортоградне положення тіла людини з системних позицій оцінюється як певна гармонія взаємопов'язаних його просторових характеристик $[6,12,13]$ (рівний розподіл м'язового тонусу між правою і лівою стороною, а також між вентральною і дорсальною лініями тулуба сприяють виконанню більш точної м'язової роботи і кращий прояв рівня збереження рівноваги тіла юних футболістів).

3. При виконанні корекційних вправ необхідно враховувати морфологічні особливості та рівень стану біогеометричного профілю постави юних футболістів і забезпечувати регламентацію та суворе дозування навантажень.

4. Корекція функціональних порушень постави юних футболістів з урахуванням рівня стану біогеометричного профілю постави, шляхом зміцнення одних груп м'язів $\mathrm{i}$ розтягування інших, що формують “м'язовий корсет” з поступовим збільшенням їх витривалості.

5. Використання фізичних вправ, які сприяють зміненню просторової орієнтації окремих біокінематичних пар ОРА, профілактики порушень біомеханіки хребетного стовпа.

6. Використання фізичних вправ, які сприяють профілактиці порушень опорноресорних властивостей стопи за рахунок збільшення сили та забезпечення необхідного тонусу скелетних м'язів нижніх кінцівок, що беруть участь в утриманні повздовжнього та поперекового склепіння стопи. 
7. Корекційні вправи повинні бути інтегровані в структуру тренувального процесу i не суперечити формуванню спеціальних навиків і фізичних здібностей у юних футболістів.

8. Фізичні вправи повинні викликати позитивні емоції і інтерес до їх виконання у спортсменів.

9. Виконання корекційних вправ необхідно здійснювати в стандартних і доступних умовах.

Підвалинами програм здоров'язберігаючої спрямованості юних футболістів 3 функціональними порушеннями ОРА слугують “Фрагменти блоків": статодинамічна постава, предметне середовище, стретчинг, рухливі ігри і естафети, корекційні критерії ефективності.

Змістовно-цільовий блок програм включає модулі: базової превентивної спрямованості та спеціальний модуль (рис. 2). Базовий модуль превентивної спрямованості змістовно-цілььового блоку програм юних футболістів сфокусований на: профілактиці порушень біомеханіки стопи, формування навички правильної статодинамічної постави.

3 огляду на той факт, що базовий модуль носитиме превентивну спрямованість, профілактичні заходи, виконувалися усіма футболістами, без диференціації на наявні функціональні порушення ОРА.

Спеціальний модуль змістовно-цілььового блоку здоров'язберігаючих програм юних футболістів орієнтований на корекцію існуючих порушень постави.

Дискусія. Нефіксовані порушення ОРА в сагітальній площинні - кругла спина. Для круглої спини характерно виражений грудний кіфоз, значне зменшення поперекового лордозу та, як наслідок, зменшення кута нахилу таза $[12,13,16]$. За наявності круглої спини виникає повна компенсація зміщення сегментів тіла - загальний центр ваги (ЗЦТ) тіла займає попереднє положення щодо площі опори, нижні кінцівки зазнають однакового навантаження, тобто змін умов вертикальної пози не відбувається (стається зміна просторової симетрії окремих біокінематичних ланцюгів і біокінематичних пар), але за допомогою додаткового зусилля м'язів і зв'язок $[12,13,16]$. Для корекції такого порушення постави використовують спеціальні фізичні вправи на розтягування м'язів передньої поверхні та зміцнення м'язів задньої поверхні тулуба 3 акцентом на розвиток як абсолютної сили, так і витривалості м'язів спини $[12,13,16]$, а також корекцію кутів нахилу голови $\left(\alpha_{1}\right)$, нахилу тулуба $\left(\alpha_{2}\right)$, підвищення рівня стану біогеометричного профілю постави та підвищення статичної рівноваги тіла юних спортсменів [12, 13, 16].

Нефіксовані порушення ОРА в сагітальній площчині - плоска спина. Для плоскої спини характерні зменшення фізіологічних вигинів хребетного стовпа, ослаблення м'язів спини та живота, а також крилоподібні лопатки та плоскі сідниці. За наявності круглої спини виникає зменшення кутів стійкості, кута нахилу таза до $30^{\circ}$ та кута нахилу голови, кута зору, моментів стійкості, переднього радіуса стійкості на тлі незмінності заднього радіуса стійкості, збільшення кута, утвореного біопарою "стегногомілка", а також зміщення ЗЦТ тіла донизу та праворуч $[12,13,16]$. Для корекції плоскої спини - через сплющення фізіологічних вигинів хребтового стовпа та зменшення кута нахилу таза - використовують фізичні вправи, спрямовані на помірне розтягування м'язів спини в грудному відділі хребтового стовпа, зміцнення м'язів спини, черевного пресу та передньої поверхні стегон, підвищення рівня стану біогеометричного профілю постави, а також вправи на само витягування, що мають бути симетричними та не спричиняти надлишковий лордоз $[12,13,16]$. 


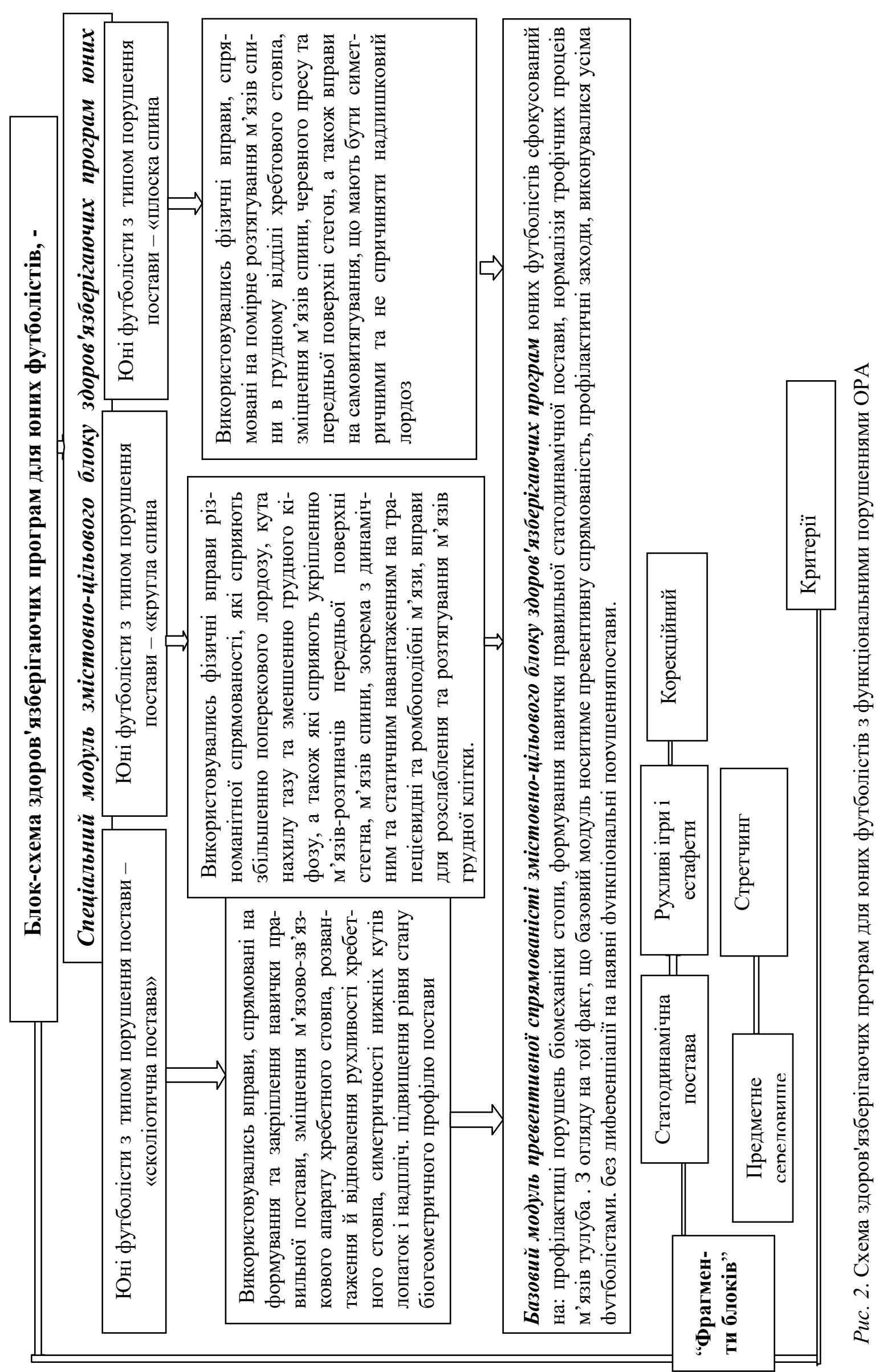


Нефіксовані порушення ОРА у фронтальній площзиі - сколіотична постава. Для сколіотичної постави характерні асиметрія положень надпліч і лопаток, нерівномірність трикутників талії. За наявності сколіотичної постави виникає зменшення кутів стійкості, кута зору та нахилу голови, кута, утвореного біопарою “стегно-гомілка", моментів стійкості, заднього радіуса стійкості на тлі незмінності переднього радіуса стійкості та незначного зміщення ЗЦТ тіла донизу та ліворуч $[12,13,16]$. Для корекції сколіотичної постави використовують вправи, спрямовані на формування та закріплення навичок правильної постави, зміцнення м'язово-зв'язкового апарату хребетного стовпа, розвантаження й відновлення його рухливості, симетричності нижніх кутів лопаток $\left(\alpha_{6}\right)$ і надпліч $\left(\alpha_{5}\right)$, підвищення рівня стану біогеометричного профілю постави та підвищення статичної рівноваги тіла юних спортсменів $[12,13,16]$.

\section{Висновок.}

1. Враховуючи фундаментальні розробки теорії та методики юнацького спорту, біомеханіки просторової організації тіла людини, специфіку планування фізичних навантажень 3 акцентом на особливості організму юних спортсменів, розроблено модель програми здоров'язберігаючої спрямованості футболістів з функціональними порушеннями опорно-рухового апарату на етапі попередньої базової підготовки та технологічні операції, яка включає два взаємопов'язаних блоки: організаційно-методичний та змістовно-цільовий.

Організаційно-методичний блок моделі програм здоров'язберігаючої спрямованості футболістів з функціональними порушеннями опорно-рухового апарату на етапі попередньої базової підготовки передбачає організацію попередньої підготовчо-методичної роботи зі створення здоров'язберігаючого середовища. Відбір доступних засобів спортивного тренування, складання плану, програми та розкладу корекційно-профілактичних заходів, підготовка спортивного інвентарю, ознайомлення юних спортсменів з особливостями виконання корекційних вправ.

У змістовно-цільовий блок програми входили мета, завдання, засоби, форми i методи корекційно-профілактичних заходів, принципи і методи проектування і реалізації здоров'язберігаючої технології. Значну увагу в ньому було приділено формуванню умінь самостійно займатися корекційними фізичними вправами і формування теоретичних знань у юних футболістів про здоров'я, здоровий спосіб життя, правильну поставу з використанням розроблених авторських мультимедійних презентацій. Змістовно-цільовій блок програм включає два модулі: базової превентивної спрямованості та спеціальний. Підвалинами програми здоров'язберігаючої спрямованості юних футболістів 3 функціональними порушеннями опорно-рухового апарату слугують “Фрагменти блоків": корекційний, статодинамічна постава, предметне середовище, стретчинг, рухливі ігри і естафети, а також критерії ефективності.

1. Випасняк I, Самойлюк О, Мицкан Т. Порівняльний аналіз фізичного розвитку юних спортсменів. Вісник Прикарпатського університету. 2019; 34: 60-68.

2. Випасняк I, Самойлюк О. Бімеханічні властивості стопи юних спортсменів як передумова розробки технології фізичної реабілітації. Молодіжний науковий вісник Східноєвропейського національного університету імені Лесі Українки. 2019; 35: 20-28.

3. Гузак О. Здоров'я юних спортсменів: аспекти спортивної спеціалізації. Journal of Education, Health and Sport. 2016;6(8):946-954. eISSN 2391-8306.

4. Кашуба ВА, Паненко НН К вопросу профилактики нарушения опорно-рессорной функции стопы у юных спортсменов. Материалы Международного научного конгресса "Стратегия развития спорта для всех и законодательных основ физической культуры и спорта в странах СНГ”. Кишинев, 2008: 479-481.

5. Кашуба ВА, Яковенко ПА, Хабинец ТА. Технологии, сберегающие и корригирующие здоровье, в системе подготовки юных спортсменов. Спортивна медицина. 2008; 2: 140-146.

6. Кашуба В, Сергиенко К, Кондаурова П. Особенности биогеометрического профиля осанки юных спортсменок, специализирующихся в художественной гимнастике. Probeme Actuale Ale Metodo- 
logiei Pregatiri i Sportivilor de Performnta. Materialele conferintei stintifice internationale. Chisinau: USEFS, (Молдова). 2010; 163-167.

7. Кашуба ВА, Ярмолинский ЛМ, Хабинец ТА. Современные подходы к формированию здоровьесберегающей направленности спортивной подготовки юных спортсменов. Физическое воспитание студентов. Харьков, 2012; 2: 34-37.

8. Кашуба ВА, Ярмолинский ЛМ. Спортивная подготовка юных спортсменов и её здоровьесберегающая направленность. Теория и методика спортивной тренировки. 2013; 1: 30-35.

9. Кашуба ВА, Ярмолинский ЛМ. Особенности биогеометрического профиля осанки юных футболистов. Научный журнал НПУ имени М.П.Драгоманова; 2013; 12(39): С. 59-63.

10. Кашуба В, Ярмолинский Л, Альошина А, Бичук О, Бичук I. Морфобіомеханічні особливості юних спортсменів на початковому етапі підготовки Молодіжний науковий вісник Східноєвропейського національного університету імені Лесі Українки. 2018; 30:175-184.

11. Кашуба ВО, Люгайло СС, Футорний СМ. Інтеграція програм фізичної реабілітації в процес першого-третього етапів підготовки спортсменів при дисфункціях систем їх організму Спортивна медицина і фізична реабілітація, № 1, 2019 C. 99-112. DOI: https: // doi.org/10.32652/spmed.2019.1.99-112.

12. Кашуба В, Лопацький С. Теоретико-практичні аспекти моніторингу просторової організації тіла людини: монографія. Івано-Франківськ: Видавець Кушнир Г.М., 2018. 232 с.

13. Кашуба В, Попадюха Ю. (2018) Біомеханіка просторової організації тіла людини: сучасні методи та засоби діагностики і відновлення порушень: монографія. К.: Центр учбової літератури. 768 с.

14. Миронюк I, Гузак О. Особливості нефіксованих порушень опорно-рухового апарату юних спортсменів на сучасному етапі. Вісник Прикарпатського університету. Серія: Фізична культура. 2019; 34: 87-93.

15. Самойлюк О. Профілактично-реабілітаційний напрямок в системі багаторічної підготовки юних спортсменів з функціональними порушеннями опорно-рухового апарату $=$ Preventive and rehabilitation direction in the system of multiple training of youth sportsmen with functional disorders of the muscular apparatus. Journal of Education, Health and Sport. [Інтернет]. 2016; 6(8): 955-964. ISSN 2391-8306.

16. Kashuba V, Andrieieva O, Yarmolinsky L, Karp I, Kyrychenko V, Goncharenko Y, Rychok T, Nosova N. Measures to prevent functional muscular disorders in sports training of 7-9-year-old football players Journal of Physical Education and Sport (JPES), 2020; Vol 20 (Supplement issue 1), Art 52: 366-371.

17. Kashuba V, Savliuk S, Vypasniak I, Yavorskyy A, Kindrat P, Grygus I, Vakoliuk A, Panchuk I, HagnerDerengowska M. Differentiated approach for improving the physical condition of children with visual impairment during physical education Journal of Physical Education and Sport ${ }^{\circledR}$ (JPES). 2020; Vol 20 (Supplement issue 2), Art 136: 958-965. Doi: 10.7752/jpes.2020.s2133

\section{References}

1. Vipasnyak I, Samoilyuk O, Mitskan T. A practical analysis of the physical development of young athletes. Visnik of the Carpathian University. 2019; 34: 60-68.

2. Vipasnyak I, Samoilyuk O. Biomechanical power of the foot of young athletes as a change in the development of technology for physical rehabilitation. Young Science Visitor of the European National University of the Ukrainian Forestry. 2019; 35: 20-28.

3. Guzak O. Health of young athletes: aspects of sports specialization Journal of Education, Health and Sport. 2016; 6 (8): 946-954. eISSN 2391-8306.

4. Kashuba VA, Panenko NN On the issue of prevention of disorders of the support-spring function of the foot in young athletes. Materials of the International Scientific Congress "Strategy for the development of sports for all and the legislative basis of physical culture and sports in the CIS countries." Chisinau, 2008: 479-481.

5. Kashuba VA, Yakovenko PA, Habinets TA. Technologies, saving and correcting health, in the system of training young athletes. Sports medicine. 2008; 2: 140-146.

6. Kashuba V, Sergienko K, Kondaurova P. Features of the biogeometric profile of posture of young athletes specializing in rhythmic gymnastics PROBLEME ACTUALE ALE METODOLOGIEI PREGATIRI I SPORTIVILOR DE PERFORMANTA. Materialele conferintei stintifice internationale. Chisinau: USEFS, (Moldova). 2010; 163-167.

7. Kashuba VA, Yarmolinsky LM, Habinets TA. Modern approaches to the formation of health-preserving orientation of sports training of young athletes. Physical education of students. Kharkov, 2012; 2: 34-37.

8. Kashuba VA, Yarmolinsky LM Sports training of young athletes and its health-preserving orientation. Theory and methodology of sports training. 2013; 1: 30-35.

9. Kashuba VA, Yarmolinskiy LM Features of the biogeometric posture profile of young football players. Scientific journal of NPU named after M.P. Dragomanov; 2013; 12 (39): 59-63.

10. Kashuba V, Yarmolinsky L, Aloshina A, Bichuk O, Bichuk I. Morphobiomechanical features of young 
athletes at the cob stage of training Young Science Newsletter of the European National University of the Ukrainian Forest. 2018; 30: 175-184.

11. Kashuba VO, Lyugailo SS, Futorniy SM. Integration of the program of physical rehabilitation in the process of the first - third stages of training athletes in case of dysfunctions of systems and their organisms Sports medicine and physical rehabilitation. 2019; 1: 99-112. Doi: https://doi.org/10.32652/spmed. 2019.1.99-112.

12. Kashuba V, Lopatsky S. Theoretical and practical aspects of monitoring the spacious organization of people. Monograph. Ivano-Frankivsk: Vidavets Kushnir G.M., 2018. 232 p.

13. Kashuba V, Popadyukha Y. (2018) Biomechanics of spacious organization of people: modern methods and methods for diagnostics and renewal of damage: monograph. K.: Center for Educational Literature. $768 \mathrm{~s}$.

14. Mironyuk I, Guzak O. The peculiarities of non-xed destructive equipment of young athletes at the current stage Visnik of the Carpathian University. Series: Physical culture. 2019; 34: 87-93.

15. Samoilyuk O. Prophylactic and rehabilitation directly in the system of baggage training of young athletes with functional damage to the musculoskeletal system= Preventive and rehabilitation direction in the system of multiple training of youth sportsmen with functional disorders of the muscular apparatus. Journal of Education, Health and Sport. [Інтернет]. 2016; 6(8): 955-64. eISSN 2391-8306.

16. Kashuba V, Andrieieva O, Yarmolinsky L, Karp I, Kyrychenko V, Goncharenko Y, Rychok T, Nosova N. Measures to prevent functional muscular disorders in sports training of 7-9-year-old football players Journal of Physical Education and Sport (JPES). 2020; Vol 20 (Supplement issue 1), Art 52: 366-371.

17. Kashuba V, Savliuk S, Vypasniak I, Yavorskyy A, Kindrat P, Grygus I, Vakoliuk A, Panchuk I, HagnerDerengowska M. Differentiated approach for improving the physical condition of children with visual impairment during physical education Journal of Physical Education and Sport ${ }^{\circledR}$ (JPES). 2020; Vol 20 (Supplement issue 2), Art 136: 958-965. Doi: 10.7752/jpes.2020.s2133

\begin{tabular}{|c|c|}
\hline \multicolumn{2}{|l|}{ Цитування на цю статтю: } \\
\hline \multicolumn{2}{|c|}{$\begin{array}{l}\text { Третяк ДЯ, Іванишин ІМ. Структура моделі програми здоров’язберігаючої спрямованості на етапі } \\
\text { попередньої базової підготовки у юних футболістів з функціональними порушеннями опорно-рухового } \\
\text { апарату. Вісник Прикарпатського університету. Серія: Фізична культура. } 2020 \text { Листоп 24; 36: 68-74 }\end{array}$} \\
\hline Відомості про автора: & Information about the author: \\
\hline $\begin{array}{l}\text { Третяк Дмитро Ярославович - аспірант, ДВНЗ } \\
\text { “Прикарпатський національний університет імені } \\
\text { Василя Стефаника” (Івано-Франківськ, Україна) }\end{array}$ & $\begin{array}{l}\text { Tretyak Dmytro Yaroslavovych - post-graduate } \\
\text { student, Vasyl Stefanyk Precarpathian National } \\
\text { University (Ivano-Frankivsk, Ukraine) }\end{array}$ \\
\hline \multicolumn{2}{|l|}{ https://orcid.org/0000-0002-7025-671X } \\
\hline $\begin{array}{l}\text { Іванишин Ірина Мирославівна-кандидат хіміч- } \\
\text { них наук, доцент, ДВНЗ “Прикарпатський націо- } \\
\text { нальний університет імені Василя Стефаника" } \\
\text { (Івано-Франківськ, Україна) }\end{array}$ & $\begin{array}{l}\text { Ivanyshyn Iryna Myroslavivna-Candidate of Scien- } \\
\text { ce (Chemistry), Associate Professor (Ph. D.), Vasyl } \\
\text { Stefanyk Precarpathian National University (Ivano- } \\
\text { Frankivsk, Ukraine) }\end{array}$ \\
\hline $\begin{array}{l}\text { e-mail: Iraivan68@gmail.com } \\
\text { https://orcid.org/0000-0003-1765-8311 }\end{array}$ & \\
\hline
\end{tabular}

УДК 796.11.3:658 doi: 10.15330/fcult.36.74-86

Роман Тягур, Володимир Мисів, Ігор Матійчук

\title{
МЕНЕДЖЕР У ФІЗИЧНІЙ КУЛЬТУРІ: ПЛАНУВАННЯ ОСОБИСТОЇ ДІЯЛЬНОСТІ
}

\author{
Час - найобмеженіший капітал, і якщзо не можеш ним \\ розпоряджатися, не зможеш розпоряджатися нічим іншим.
}

Пітер Друкер

\begin{abstract}
Мета. Розкрити роль та значення планування у роботі менеджера, охарактеризувати зміст планування особистої праці менеджера у фізичній культурі. Методи. Для реалізації поставленої мети були використані наступні методи дослідження: теоретичний аналіз і узагальнення науково-методичної літератури. Результати. Встановлено, що функиї менеджера у фізичній культурі багатогранні: загальне керівництво діяльністю організації, координація дій підрозділів і служб, робота з кадрами, визначення цілей $і$ завдань діяльності, прийняття рішень, представниџтво організації у стосунках з інши-
\end{abstract}

(C) Тягур Р., Мисів В., Матійчук I., 2020 